\title{
Nota do editor para esta edição brasileira
}

Esta é uma edição especial da revista Avaliação. Reunimos na mesma edição alguns dos mais renomados estudiosos da educação superior latino-americana e européia. Os textos representam um amplo balanço, de forma comparada, da educação superior da América Latina e do Caribe. Por isso, os textos são apresentados em espanhol. Estes mesmos textos serão amplamente divulgados no mundo; em futuro próximo, serão editados em livros em espanhol e em inglês. O leitor da América Latina e do Caribe tem o privilégio de conhecer em primeira mão, mediante esta edição da revista Avaliação, os estudos e análises de 15 intelectuais de alto reconhecimento internacional, a respeito de vários sistemas de educação superior do Continente, antes mesmo que os leitores de outras partes do mundo. Somos muito gratos à magnanimidade dos editores e dos autores dos diversos textos, que concederam à revista Avaliação o privilégio desta edição brasileira.

Com esta edição muito especial, estamos também comemorando os doze anos completos desta revista. A criação de Avaliação como revista de estudos e análises da temática de educação superior, de modo particular, da avaliação da educação superior, se deu no dia 26 de abril de 1996, na cidade do Recife. O primeiro número, que saiu em julho do mesmo ano, foi planejado em Florianópolis, por este editor e pelo editor adjunto (Dilvo Ristoff) e já contou com textos de alguns autores que até hoje contribuem para a consolidação deste periódico. Desde então, já lançamos 47 edições, com uma perspectiva crescentemente internacional, sobretudo ibero-americana. É o momento de agradecermos a todos os nossos colaboradores, especialmente aos membros do Conselho Editorial, autores e assinantes. Devemos agradecer de modo particular ao apoio da Universidade de Sorocaba (Uniso), que desde 2007 se tornou parceira da RAIES para a publicação desta revista.

Normalização. Em virtude de esta edição trazer textos de especialistas de diversos países da América Latina e da Europa, optamos por manter e respeitar as normas de publicação seguidas por seus respectivos autores. As normas adotadas nestes textos por seus autores podem não coincidir plenamente com as prescrições da $\mathrm{ABNT}$ recomendadas para as edições ordinárias da revista Avaliação. 